\title{
The Procedure of Distribution of $20 \%$ from the Sale of Socially Owned Enterprises
}

\author{
Bleta Brovina \\ University of Prishtina - Faculty of Law \\ bleta.brovina@uni-pr.edu
}

\author{
Doi:10.5901/ajis.2015.v4n1s2p53
}

\section{Abstract}

Distribution process of $20 \%$ from the sale of Socially Owned Enterprises (SOE) is one of the most sensitive processes of Kosovo's society. This process has begun in 2003 and continues today. The largest number of protests that occurred in Kosovo are due to disappointment in the slow process of distribution of $20 \%$ from the sale of SOEs. The aim of the work presented in this paper is to analyse the distribution of the $20 \%$ from the sale of SOEs, changes to this process and the impact on former employees of privatized SOEs. In order to understand these aspects, the available data were analysed qualitatively and quantitatively. In addition, I have used several methods of analysis, including empirical and normative methods, and analysis of legal provisions. Results of the data analysis show that changes in the legal framework have not affected the shape and dynamics of the distribution process. However, a pragmatic solution that was applied by Privatization Agency of Kosovo (PAK), a solution that is not provided within legal provisions, has made it possible to accelerate this process. This solution consists of the following formula: the $20 \%$ from the sale of the SOE is calculated in two parts; the first part is related to the number of SOE workers without claims, and the second part is related to the number of SOE workers with claims submitted in Special Chamber of Supreme Court (SCSC). The first part is distributed to SOE workers, while the second part, is distributed after the final decision of the SCSC. However, despite this solution, when the decisions of the SCSC on matters of Privatization Agency of Kosovo are analysed, it results that there are still further possibilities for this process to be accelerated and to be simplified even more.

Keywords: Privatisation Agency of Kosovo, 20\%, Socially Owned Enterprise, SOE, Special Chamber of the Supreme Court

\section{Introduction}

Period of post-conflict of 1999 had changed the political landscape of Kosovo. These political changes had a knock-on effect on and the legislative and economical spheres. Considering that before year 1999, Kosovo did not have a free market-based economy and many of the holdings were socially owned, necessitated approval of legal infrastructure that allowed transformation of holdings from the social ownership to private ownership.

Kosovo's privatization process is the last to occur in the region. It began in 2002, at a time when the final political status of Kosovo was still under negotiation. Therefore, under these circumstances the privatisation process is seen as atypical. However, as soon as the privatisation process began, so began the dissatisfaction of the workers of socially owned enterprises. By the year 2003, a law was enacted that recognised the rights of these workers to a share of $20 \%$ from the sale price of the enterprise.

This aim of this paper is to analyse the distribution process of the $20 \%$ share, based on Privatisation Agency of Kosovo (PAK)'s authority on this process. While the Kosovo's privatisation process has been studied before (Gashi, 2013; Tondini 2003; Farcnik, 2007), the process of distribution of $20 \%$ on the other hand, has not been studied.

Considering that the distribution of $20 \%$ is a sensitive process, particularly in relation to the workers of the socially owned enterprises, PAK has applied a formula on distribution of means, in order to accelerate this process. The current procedure in vigour is divided in 11 stages. However, an analysis of the decisions of the Special Chamber of Supreme Court (SCSC), reveals that this process can be further accelerated and simplified, favouring both the workers of SOE and also PAK.

\section{The Legal Framework for the Distribution of the $20 \%$ Share from the Sale of Soe}

The legal framework for the commencement of the privatisation process has been established in 2002. In June of 2002, UNMIK Regulation 2002/12 was enacted, which allowed establishment of Kosovo Trust Agency (KTA). KTA was established under the Fourth Pillar of United Nations Interim Administration Mission in Kosovo (UNMIK), whose objective 
was economic development of Kosovo. Amongst other tasks, KTA was authorised to administer and sell SOEs. The above-mentioned law stipulated that the income generated from the sale of the shares of SOEs should benefit the creditors and the owners, under the condition that the income is trusted to the KTA. However, this raises the question: who are in fact creditors and who are the owners? What about the workers of the SOEs, are they considered to be creditors or are they considered owners? This provision was not specified by the Regulation.

The UNMIK Regulation 2003/13 that entered in force on the $9^{\text {th }}$ of May 2003, provisioned a special status for the SOE workers and recognised their right to $20 \%$ from the sale of the SOE ${ }^{1}$. The remaining $80 \%$ of the sale price is to be used to compensate the requests of the creditors, based on the Law No. 04/-L-035. In order to gain the right to $20 \%$ the workers are asked to fulfil two conditions:

1) To be registered as a worker of the SOE during the privatisation process; and

2) To be on the payroll of the SOE for more than 3 years (in accordance to the article 10 of the UNMIK Regulation regarding transformation of the rights on the use of socially owned property)

As an exception, the other workers that do not fulfil the two conditions above, may also apply for a share of $20 \%$ provided that Special Chamber of the Supreme Court recognises their right to participation on the 20\% (Refer to UNMIK Regulation no.2002/13 on the establishment of Special Chamber of Supreme Court on Kosovo Trust Agency Related Matters amended by Regulations No. 2008/4 and No. 2008/19, repealed by Law on the Special Chamber of the Supreme Court of Kosovo on Privatization Agency Related Matters)

\section{Beginning of the Procedure for the Distribution of the $20 \%$}

The procedure for the distribution of $20 \%$ begins after public sale of the SOE. The signing of the contract for the sale of SOE concludes the sale process and opens the way for the commencement of the distribution process of the $20 \%$. Socially Owned Enterprise together with the Federation of Independent Unions of Kosovo (FIUK) are responsible for the compilation of the list of the workers that are entitled to the $20 \%$. Within the current practices, the Socially Owned Enterprise is represented by the council of workers. If the council of workers does not exist, the management of the Socially Owned Enterprise together with the FIUK compile the list of eligible workers. In cases when there were no workers part of the Socially Owned Enterprise, PAK has provided public notices and gathered necessary information in order to find the workers that were part of the Socially Owned Enterprise. In cases when it was impossible to find any of the workers then the list of eligible workers was compiled by the FIUK. Completed lists were provided to PAK for further review.

\subsection{Specifics on the Review of the Workers Lists and Distribution of 20\% at Pak}

On the basis of PAK regarding the distribution of $20 \%$, the process comprises the following eleven stages:

1) review of the workers' lists provided by the management of Socially Owned Enterprise and FIUK

2) publication of preliminary lists in the newspapers

3) acceptance of any complaints regarding the preliminary lists until the date specified by PAK

4) review of eventual complaints against published preliminary lists

5) compilation of the final lists

6) approval of the final lists by the Board of Directors of PAK

7) publication of final lists on the newspapers as stipulated by the law (Article 10.3, law 2003/13 regarding article 10.6 (a))

\footnotetext{
1 UNMIK Regulation 2003/13, as amended by Regulation 2004/45 is the only UNMIK Regulation on privatization, which is not repealed and amended by the law of the Assembly. Regarding the issue of repealing the UNMIK Regulation through the laws of the assembly of Kosovo, there was a collision of thoughts. UNMIK Legal Opinion (UNMIK / REG / 2008 / 4- clarification, 12 January 2009) clarifies that the assembly laws can not abolish UNMIK regulations, as does the law of PAK 03 / L-067, which repeals the KTA Regulation No.2002 / 12. Thus, the Law of the Assembly (in this case the Law on Privatization Agency-PAK, successor of Kosovo Trust Agency- KTA) serves only as an internal regulation. However, the decision of the Constitutional Court, ref. AG 109/2011, in the case KI 25/10, Privatization Agency of Kosovo against the decision of the Special Chamber of the Supreme Court, ASC-09-089, paragraphs, 53-57, considers such an attitude is violation of law in Kosovo, Kosovo Constitution and Ahtisaari's Comprehensive Plan and ignoring the existence of Kosovo as a state. For more details see: Gashi, H, 2011. "The legal conflict over privatization of SOEs: Changing the Law on the Special Chamber of the Supreme Court, PAK Law and relevant laws" GAP. Available at: http: //www.institutigap.org/documents/7627_AKP.pdf
} 
8) acceptance of any complaints against the final lists from the Special Chamber of Supreme Court (SCSC) and provisioning of a response

9) representation of Socially Owned Enterprise under administration of PAK regarding the final lists, until a decision has been reached by the SCSC.

10) distribution of the $20 \%$, depending on the number of complaints received regarding the final lists of workers, according to the PAK's formula

11) implementation of second instance decision of SCSC regarding distribution of the $20 \%$, after receiving it from PAK

Some of the above stages cannot be precisely estimated time-wise. This is because the length of some of these stages is dependent on other, external factors. However, in general the following table provides an estimate of time span of different stages.

Table 1. Estimated timespan of different stages of distribution of $20 \%$

\begin{tabular}{|ll|ll|}
\hline 1. & Stage number & 2. & Estimated time \\
\hline 3. & 1 & 4. & Unspecified \\
\hline 5. & 2 & 6. & One working day, and 2 days (during the weekend) \\
\hline 7. & 3 & 8. & 20 days \\
\hline 9. & 4 & 10. & 20 days \\
\hline 11. & 5 & 12. & Unspecified \\
\hline 13. & 6 & 14. & The next meeting of the Board of Directors of PAK (held once a month) \\
\hline 15. & 7 & 16. & Two working days (during the weekend) \\
\hline 17. & 8 & 18. & 5 days after receiving the complaint by the SCSC (time to appeal is 20 days) \\
\hline 19. & 9 & 20. & Dependent on the priorities of SCSC \\
\hline 21. & 10 & 22. & Unspecified \\
\hline 23. & 11 & 24. & Dependent on the priorities of SCSC \\
\hline
\end{tabular}

\subsection{Application of Formula for Early Distribution of $20 \%$ by Pak}

There were 15.657.120 Euro distributed during the mandate of KTA, while PAK has distributed 98.749.869 Euro. From this process benefitted around 44.000 workers of SOEs. The distribution process was delayed because the distribution did not occur prior to a decision by SCSC. Considering the sensitivity of this issue and the pressure from the workers of SOE, PAK found itself in a situation that required a solution. In response PAK specified a formula for the early distribution of $20 \%$. According to this formula, in cases when a decision by SCSC has not been taken regarding the lists of workers, PAK asks SCSC for the number of possible complaints against the lists of workers. As such, the early distribution of $20 \%$ is given only to workers that are on the final lists and there are no complaints against them.

\subsection{Analysis of Court Practices Based on the Decisions of Scsc Regarding Procedural Aspects of Distribution of 20\%}

As can be seen from the table above, the privatisation process undergoes through a large number of stages. However, the question remains whether all the stages are necessary? An analysis of SCSC decisions regarding this issue reveals that this process could be shortened and simplified.

In the past, the KTA has not reviewed the lists and workers were in position to file complaints directly to the SCSC (see Termosistemi vs. AKM-së, SCEL 04-0001). Later, KTA, now PAK, takes an active role related to compilation of preliminary lists, which prolongs the process of distribution of $20 \%$.

In its decision SCSC has dedicated a special chapter the issue of whether to file an appeal in the preliminary lists. The court found that there is no limit to the possibility of submitting a claim to the SCSC, that is filing the appeal prior to the PAK. Further, it is noted that no reference is found in relation to the provisional lists. It was emphasized that it is not necessary to exhaust administrative means before addressing the court. The court comes to the conclusion that there is no need to file an appeal against the preliminary list (Drithnaja vs. AKP, SCEL-11-0063).

This means that the PAK does not need to develop the process of distribution of $20 \%$ in 11 phases. What would be the point of the existence of the notion and procedures relating to the preliminary lists, as the court does not see fit the existence of complaints regarding the preliminary lists? Perhaps the PAK should think back to its passive role regarding the stages of preliminary lists, in favour of simplicity, economy and accelerating the procedure. Institutions of the Republic 
of Kosovo are already committed to completion of the privatization process within the 2-3 year timeframe, which requires simplification, acceleration and efficiency of internal procedures of PAK (see http://www.rtklive.com/?id=3\&r=20030). Reducing the phases associated with the preliminary lists would shorten the process of distribution of $20 \%$ to the first 5 stages. The role of the PAK could begin with the approval of lists of employees by the Board of Directors and their publication. In this way the PAK budget dedicated to the publication of the preliminary lists could be spared.

\section{Conclusion}

Analysis of the decisions of the Special Chamber of the Supreme Court and the history of legal regulation of the process of distribution of $20 \%$ from the sale of SOEs, reveals the possibility of shortening the procedure, its timeline and its simplification. All this would be performed within an internal reorganization of the process of distribution of $20 \%$ within the PAK and harmonization of the current legislation accordingly.

This reorganization will benefit workers of SOEs both in terms of time and money. PAK would benefit from the budgetary aspect, saving costs incurred in connection with several stages of this process. In this way, the acceleration of procedures for the allocation of $20 \%$ will serve as social stabilizer. This would impact on the acceleration of the privatization process in general. Performing faster privatization process will unblock privatization funds, which will be passed on to the Kosovo budget and be used for economic development, which is crucial for the future of the country.

\section{References}

Gashi, H ( 2011), "The legal conflict over privatization of SOEs: Changing the Law on the Special Chamber of the Supreme Court, PAK Law and relevant laws" GAP. Available at: http: //www.institutigap.org/documents/7627_AKP.pdf

Gashi H (2013)," A Comparative Analysis of the Transformation of State/Social Property: Privatization and Restitution in the PostCommunist Countries - Kosovo as a Sui Generis Case of Privatization", PhD, Universiteti i Bremenit

Tondini, M (2003) "The privatisation system in Kosovo- rising towards an uncertain future" , Prishtina

Farnic, P (2007) " The privatisation process in Kosovo - an overview and some recommendations, Diploma paper, Lubljana, OSCE Organisation for security and cooperation in Europe, Monitoring Department/Rule of Law division, 2008. Privatisation in Kosovo: Legal analyze of Kosovo Trust Agency related matters from the Special Chamber of Supreme Court, page 16

Sylqa, D, 'Privatisation Vs Re-privatisation". Available at: http://www.dukagjinicollege.eu/libri/driton_sylqa.pdf

UNMIK Regulation no.2002/13, On the Establishment of a Special Chamber of the Supreme Court of Kosovo on Kosovo Trust Agency Related Matters amended by Regulations No. 2008/4 and No. 2008/19]available at: http://www.unmikonline.org/regulations/ unmik gazettel

UNMIK Regulation no.2002/12 On the Establishment of the Kosovo Trust Agency , amended by Regulations No. 2005/18, No. 2008/16 and No. 2008/27 available at: http://www.unmikonline.org/regulations/unmikgazette/

UNMIK Regulation 2003/13 On the Transformation of the Right of Use to Socially-Owned Immovable Property, amended by UNMIK Regulation No. 2004/45 on the Transformation of the Right of Use to Socially-owned Immovable Property, available at: http://www.unmikonline.org/regulations/unmikgazette/

Law on Privatisation Agency of Kosovo no. 03/L-067 available at: http://www.pak-ks.org/?page=2,28

Law on Privatisation Agency of Kosovo no. 04/L-034, Official Gazette of the Republic of Kosova / NO. 19 / 21 September 2011, Pristina

Law No. 04/L-033 on the Special Chamber of the Supreme Court of Kosovo on Privatization Agency Related Matters, Official Gazette of the Republic of Kosova / No. 20 / 22 September 2011, Pristina 